Syntax Literate : Jurnal Ilmiah Indonesia p-ISSN: 2541-0849

e-ISSN : 2548-1398

Vol. 5, No. 2 Februari 2020

\title{
PENGARUH POLITISASI SARA TERHADAP TINGKAT PARTISIPASI MASYARAKAT UNTUK MENGIKUTI PEMILIHAN PRESIDEN TAHUN 2019
}

\author{
Ujang Permana dan Idris Handriana \\ Sekolah Tinggi Ilmu Kesehatan (STIKes) YPIB Majalengka \\ Email: ujangpermana1974@gmail.com dan idrishandriana19@yahoo.co.id
}

\section{Abstract}

Ahead of the 2019 Presidential Election, the use of SARA sentiments as a political instrument to attack political opponents and gather political support increasingly adorns public space. It is feared that the increasing number of SARA politicization efforts will continue to influence the level of public participation in the 2019 Presidential Election. This study aims to determine the extent of the influence of SARA politicization on the level of community participation to participate in the 2019 Presidential Election in Cigasong District, Majalengka Regency. This research is descriptive qualitative research which is divided into two stages, namely the first stage of preliminary research and the second stage of main research. Based on the results of this study, it can be seen that the SARA politicization that has been sticking up before the 2019 Presidential Election does not affect the level of community participation to participate in the 2019 Presidential Election in Cigasong Sub-District, Majalengka Regency. Based on the data obtained by researchers, it was found that community participation in the 2019 Presidential Election in Cigasong Subdistrict, Majalengka Regency was quite high, amounting to $85.58 \%$. The community remains enthusiastic to cast their votes in the hope that the momentum of the 2019 Presidential Election will bring positive changes to people's welfare. This research is theoretically expected to support the concept of education, especially Pancasila Education and Citizenship which studies the democratic process because discussing the issue of SARA that continues to develop ahead of the 2019 Presidential Election is expected to be input for supervisors and election administrators to take anticipatory steps so that the level of community participation in participating in the elections remains high and the democratic process can be passed conducive

Keywords: SARA politicization, community participation, Presidential Election

\begin{abstract}
Abstrak
Menjelang pelaksanaan Pemilihan Presiden 2019, penggunaan sentimen SARA sebagai instrumen politik untuk menyerang lawan politik dan menghimpun dukungan politik semakin menghiasi ruang publik. Semakin banyaknya upaya politisasi SARA yang terus berkembang, dikhawatirkan dapat mempengaruhi tingkat partisipasi masyarakat untuk mengikuti Pemilihan Presiden tahun 2019. Penelitian ini bertujuan untuk mengetahui sejauhmana pengaruh politisasi SARA terhadap tingkat partisipasi masyarakat untuk mengikuti Pemilihan Presiden Tahun 2019 di Kecamatan Cigasong Kabupaten Majalengka. Penelitian ini merupakan penelitian kualitatif deskriptif yang
\end{abstract}


terbagi dalam dua tahap yaitu tahap pertama penelitian pendahuluan dan tahap kedua penelitian utama. Berdasarkan hasil penelitian ini, dapat diketahui bahwa politisasi SARA yang selama ini mencuat menjelang Pilpres 2019 tidak mempengaruhi tingkat partisipasi masyarakat untuk mengikuti Pemilihan Presiden Tahun 2019 di Kecamatan Cigasong Kabupaten Majalengka. Berdasarkan data yang peneliti peroleh, didapatkan hasil bahwa partisipasi masyarakat pada Pemilihan Presiden 2019 di Kecamatan Cigasong Kabupaten Majalengka cukup tinggi, yakni sebesar $85,58 \%$. Masyarakat tetap antusias untuk memberikan suaranya dengan harapan momentum Pilpres 2019 akan membawa perubahan positif terhadap kesejahteraan masyarakat.Penelitian ini secara teoritis diharapkan dapat mendukung konsep ilmu pendidikan khususnya Pendidikan Pancasila dan Kewarganegaraan yang mengkaji tentang proses demokrasi, karena membahas tentang isu SARA yang terus berkembang menjelang Pemilihan Presiden 2019 diharapkan menjadi bahan masukan bagi pengawas dan penyelenggara pemilu untuk melakukan langkahlangkah antisipatif sehingga tingkat partisipasi masyarakat untuk mengikuti Pemilu tetap tinggi dan proses demokrasi dapat dilalui secara kondusif.

Kata kunci: politisasi SARA, partisipasi masyarakat, Pemilihan Presiden

\section{Pendahuluan}

Pemerintahan yang kuat adalah pemerintahan yang dapat dukungan penuh dari rakyatnya (Harnawansyah, 2019). Menjelang pelaksanaan Pemilihan Presiden 2019, penggunaan sentimen Suku, Agama, Ras, dan Antar-golongan (SARA) sebagai cara yang jitu untuk membunuh lawan politik di ruang publik. Baik di kalangan elite maupun di tingkat akar rumput, intensitas penggunaan sentimen isu ini semakin tinggi. Perkembangan ini bisa merusak nilai kebhinekaan dan toleransi.

Menguatnya isu SARA menjelang Pemilihan Presiden bukan hanya dinamika politik yang tidak konstruktif, tapi juga sangat berbahaya. Apalagi penggunaan dan penyebarannya di ruang publik banyak dilengkapi dengan ujaran kebencian yang memupuk benih-benih perpecahan di tengah masyarakat. Setiap tindakan yang melibatkan kekerasan, diskriminasi dan pelecehan yang didasarkan pada identitas diri dan golongan dapat dikatakan sebagai tindakan SARA (Sumardiana, 2016).

Isu SARA memang tidak dapat dengan mudah dipisahkan dalam dunia politik. Isu SARA kelapkali berada pada bahsan komunikasi politik. Hal ini dipakai sebagai alat pendekatan atau penyerangan bagi kalangan etnis tertentu.

Di negara Amerika maupun Prancis, isu SARA ini menjadi guru demokrasi. Dalam konteks Indonesia, datangnya angin demokrasi tidak serta-merta menghapuskan sentimen SARA itu. Terangkatnya isu SARA berhubungan dengan pelaksanaan pemilu yang terbukti mempunyai efek suram.

Pada level akar rumput, sayangnya para juru kampanye tak jarang membahasakan isu yang berbau SARA, dengan demikian mencolok dan cenderung dekat dengan fitnah ketimbang realitas, demi menarik perhatian khalayak.

Semakin derasnya isu SARA yang terus berkembang, dikhawatirkan dapat mempengaruhi tingkat partisipasi masyarakat untuk mengikuti Pemilihan Presiden 
tahun 2019. Berdasarkan hal tersebut, maka peneliti bermaksud untuk melakukan penelitian yang berjudul "Pengaruh Politisasi SARA Terhadap Tingkat Partisipasi Masyarakat untuk Mengikuti Pemilihan Presiden Tahun 2019 di Kecamatan Cigasong Kabupaten Majalengka".

\section{Metode Penelitian}

Untuk mengetahui pengaruh politisasi SARA terhadap tingkat partisipasi masyarakat Kecamatan Cigasong Kabupaten Majalengka untuk mengikuti Pemilihan Presiden tahun 2019, peneliti menerapkan metode penelitian kualitatif deskriptif yaitu menjelaskan atau menerangkan peristiwa (Anggito \& Setiawan, 2018). Pada penelitian ini, peneliti ingin mendeskripsikan suatu fenomena (politisasi SARA) sesuai dengan keadaan yang sebenarnya dialami oleh subjek penelitian dan menyajikan data tersebut dalam bentuk kata-kata.

Lokasi Penelitian dilaksanakan di Kecamatan Cigasong Kabupaten Majalengka pada tahun 2019 dengan waktu penelitian mulai Bulan Februari sampai dengan Oktober tahun 2019. Jenis dan sumber data dalam penelitian ini adalah data hasil pengamatan dan wawancara yang berhubungan dengan pengaruh politisasi SARA terhadap tingkat partisipasi masyarakat Kecamatan Cigasong Kabupaten Majalengka untuk mengikuti Pemilihan Presiden tahun 2019. Teknik penelitian yang penulis gunakan adalah teknik wawancara, observasi langsung dan dokumentasi (Nawawi, 1993).

\section{Hasil dan Pembahasan}

Hasil penelitian ini berpedoman pada data yang berasal dari hasil wawancara, observasi dan dokumentasi. Aspek yang menjadi kajian dalam penelitian ini adalah pengaruh politisasi SARA terhadap tingkat partisipasi masyarakat untuk mengikuti Pemilihan Presiden Tahun 2019 di Kecamatan Cigasong Kabupaten Majalengka.

Analisis data yang digunakan dalam penelitian ini meliputi pengumpulan data, reduksi data, display data, dan penarikan kesimpulan. Penelitian ini menggunakan interpretasi data secara deskriptif berupa uraian kalimat sebagai berikut.

\section{a. Politisasi SARA Menjelang Pemilihan Presiden Tahun 2019 di Kecamatan Cigasong Kabupaten Majalengka.}

Berdasarkan hasil wawancara yang dilakukan peneliti dengan studi kasus di Kecamatan Cigasong Kabupaten Majalengka, dapat diketahui bahwa tidak ditemukan politisasi SARA di Kecamatan Cigasong. Hal itu terlihat dari wawancara dengan Ketua Panitia Pengawas Kecamatan (Panwascam) Kecamatan Cigasong, Iim Ibrahim, S.Sos, SE, MM berikut ini.

"Selama ini kami belum pernah mendapatkan laporan dari masyarakat tentang politisasi SARA menjelang Pilpres tahun ini. Demikian pula berdasarkan pengawasan kami selama ini. Baik sejak panitia pengawasan ini dibentuk tahun 2018 hingga pada masa kampanye, saat pemungutan suara hingga proses perhitungan suara dan penetapan hasil Pilpres 2019 
di Kecamatan Cgasong Alhamdulillah berjalan dengan baik. Kalaupun ada pelanggaran tidak terkait dengan masalah SARA"

Selain Ketua Panitia Pengawas Kecamatan (Panwascam) Kecamatan Cigasong, Camat Cigasong Saleh, S.Sos mengatakan :

"Menjelang Pilpres maupun pada saat pelaksanaan pemilihan alhamdulillah aman-aman saja. Tidak ada gejolak apapun, apalagi dengan masalah SARA. Mungkin karena masyarakat Cigasong sudah memahami pentingnya menjaga kondusifitas dalam menghadapi pemilu tahun ini."

Hal senada dikatakan tokoh masyarakat H. Yayan terkait ada tidaknya politisasi SARA di Kecamatan Cigasong.

"Di Kecamatan Cigasong isu-isu tentang SARA mungkin hanya diperoleh warga dari internet atau media social dan hal itu tidak terlalu memberikan pengaruh yang negative sehingga kehidupan bermasyarakat di sini berjalan baik-baik saja. Tidak pernah ditemukan adanya provokasi kelompok tertentu tentang SARA apalagi upaya politisasi SARA menjelang Pilpres untuk memenangkan salah satu Paslon di kecamatan ini."

Sedangkan AS, salah seorang warga Kecamatan Cigasong yang peneliti wawancarai dengan tegas mengatakan,

"Masyarakat Cigasong cinta damai. Jadi mau Pilpres ataupun bukan akan selalu hidup rukun. Masalah SARA di kecamatan Cigasong tidak pernah terjadi. Kami hidup saling berdampingan, fokus dengan pekerjaan masing-masing dan jika ada yang mendapatkan musibah kami terbiasa saling tolong menolong tanpa harus melihat latar belakang sosial dan lain sebagainya"

\section{b. Partisipasi Masyarakat untuk Mengikuti Pilpes 2019}

Berdasarkan data yang peneliti peroleh, didapatkan hasil bahwa partisipasi masyarakat pada Pemilihan Presiden 2019 cukup tinggi, yakni sebesar 85,58\%. Peneliti memperoleh data secara akurat dari tiap desa terkait jumlah patisipasi masyarakat dalam mengikuti Pemilihan Presiden 2019 yang dapat diuraikan sebagai berikut : 
Tabel 1

Jumlah Partisipasi Masyarakat Kecamatan Cigasong Kabupaten Majalengka Untuk Mengikuti Pemilihan Presiden 2019

\begin{tabular}{clccc}
\hline \multirow{2}{*}{ No } & Kelurahan/Desa & $\begin{array}{c}\text { Hak } \\
\text { Pilih }\end{array}$ & $\begin{array}{c}\text { Yang } \\
\text { Memilih }\end{array}$ & $\%$ \\
\hline 1. & Kelurahan Cigasong & 4.160 & 3.572 & 85,86 \\
\hline 2. & Simpeureum & 2.303 & 2.005 & 87,06 \\
\hline 3. & Cicenang & 3.349 & 2.933 & 87,58 \\
\hline 4. & Kawunghilir & 628 & 537 & 85,51 \\
\hline 5. & Tajur & 2.449 & 2.079 & 84,90 \\
\hline 6. & Tenjolayar & 2.962 & 2.466 & 83,25 \\
\hline 7. & Baribis & 3.330 & 2.884 & 86,61 \\
\hline 8. & Batujaya & 2.177 & 1.864 & 85,62 \\
\hline 9. & Kutamangu & 2.377 & 2.059 & 86,62 \\
\hline 10. & Karayunan & 3.411 & 2.834 & 83,08 \\
\hline & Jumlah & 27.146 & 23.233 & 85,58 \\
\hline
\end{tabular}

Selain berdasarkan data tertulis, peneliti juga memperoleh data berdasarkan hasil wawancara dengan warga, tokoh masyarakat, Panwascam maupun aparatur pemerintahan Kecamatan Cigasong terkait tingginya partisipasi masyarakat untuk mengikuti Pilpres 2019 yang dapat dipaparkan sebagai berikut.

"Alhamdulillah pada Pilpres tahun ini saya bisa menyampaikan pilihan saya ke TPS. Meskipun banyak sekali berita berseliweran di medsos tapi tidak membuat saya jadi enggan untuk mengikuti pencoblosan. Malah saya semakin yakin bahwa saya harus bisa ikut Pilpres" (Warga Desa Cicenang Kecamatan Cigasong Kabupaten Majalengka, Agus)

"Saya melihat sendiri bagaimana warga berduyun-duyun datang ke TPS untuk memberikan suaranya. Sejak pagi mereka datang sehingga sebelum batas akhir waktu pencoblosan banyak TPS yang sudah selesai melaksanakan proses pemungutan suara” (Kepala Desa Karayunan Kecamatan Cigasong Kabupaten Majalengka)

"Tadinya sempat khawatir pada momentum Pilpres tahun 2019 ini partisipasi masyarakat akan turun atau banyak yang golput. Ternyata tidak, partisipasi masyarakat cukup tinggi untuk mengikuti Pilpres 2019”. (Joyo Suhindra, Sekretaris Kecamatan Cigasong)

Selain melakukan wawancara, peneliti melakukan observasi dan pengamatan secara mendalam, seperti turut memantau kegiatan Rapat Pleno Terbuka Rekapitulasi dan Penetapan Daftar Pemilih Tambahan (DPTb) tahap 2 bertempat di Aula Kecamatan Cigasong, PPK Kecamatan Cigasong pada hari Jumat, 8 Maret 2019, pukul 20.00 WIB. Dalam rapat pleno terbuka ini dihadiri oleh Camat Cigasong diwakili oleh Sekcam Joyo Suhindra, Kapolsek Cigasong 
AKP. Romdani, SH, Ketua dan anggota PPK Cigasong, Ketua dan anggota Panwascam Cigasong serta Ketua PPS se-Kecamatan Cigasong dan perwakilan Partai Politik di Kecamatan Cigasong. Dalam kesempatan itu, Kapolsek Cigasong Polres Majalengka AKP Romdani SH menjelaskan bahwa Polsek Cigasong selalu menjalin komunikasi dan koordinasi dalam tiap tahapan Pemilu 2019 dengan harapan akan lebih mudah dalam memetakan kerawanan-kerawanan Pemilu 2019, sehingga akan lebih maksimal dalam pelaksanaan pengamanan nantinya.

Sedangkan hasil pengamatan peneliti, setiap desa tampak kondusif, tidak terjadi gesekan permasalahan SARA antar warga. Hal serupa terlihat saat observasi peneliti di lapangan ke sejumlah TPS di Kecamatan Cigasong pada hari pemungutan suara. Antusiasme masyarakat untuk berpartisipasi mengikuti Pilpres 2019 cukup tinggi. Tidak ada keluhan yang diterima peneliti dari petugas KPPS terkait partisipasi warga.

c. Pengaruh Politisasi SARA Menjelang Pemilihan Presiden Tahun 2019 di Kecamatan Cigasong Kabupaten Majalengka

Banyak pihak mengkhawatirkan politisasi isu suku, agama, ras dan antargolongan berpotensi menjadi hambatan terbesar dalam konsolidasi demokrasi, dan penyelenggaraan Pemilu 2019. Hal ini terungkap dalam hasil Survei Ahli 2018 yang dilakukan Pusat Penelitian Politik Lembaga Ilmu Pengetahuan Indonesia (LIPI) pada periode April hingga Juli 2018. 145 Ahli yang terlibat dalam survei tersebut tidak lain memiliki maksud untuk melihat sejauhmana potensi masalah yang muncul dalam pemilu 2019. Politisasi isu suku, agama, ras, dan antar golongan (SARA) masuk di tiga bidang, yakni politik, sosial budaya, dan hankam. Potensi hambatan terbesar muncul dari bidang politik, kemudian konflik horizontal antar pendukung pasangan calon, gangguan keamanan, kurang siapnya penyelenggara pemilu, dan tidak netralnya pemilu 2019.

Selain bidang politik, bidang sosial budaya juga memiliki potensi hambatan yang cukup besar, yakni sebesar 40\%. Selain itu intoleransi sebesar 21\%, radikalisme $10 \%$, rasa saling curiga dalam masyarakat $7 \%$ dan hoaks $7 \%$. Di bidang hankam, potensi konflik sosial dan politisasi SARA itu melebur menjadi satu sebesar 42,5\%, menyusul kemudian aksi terorisme 16,2 \%, keberpihakan apparat $14,1 \%$, dan radikalisme $6,1 \%$.

Akan tetapi, kekhawatiran itu tidak peneliti temui di lokasi penelitian yakni di Kecamatan Cigasong Kabupaten Majalengka. Berdasarkan penelitian yang dilakukan peneliti dengan studi kasus di Kecamatan Cigasong Kabupaten Majalengka, dapat diketahui bahwa tidak terjadi politisasi SARA di Kecamatan Cigasong. Selain itu, isu SARA yang diperoleh masyarakat hanya diperoleh melalui media social, sedangkan di tengah masyarakat kecamatan Cigasong hal tersebut tidak mencuat.

Penelitian ini bertolak belakang dengan penelitian (Kharisma, 2017) tentang konflik SARA pada pilkada DKI Jakarta di Grup Whatsapp dengan Anggota Multikultural yang mempengaruhi kondisi sosial di lapangan. Meskipun politisasi 
SARA banyak diperoleh warga melalui media sosial akan tetapi masyarakat kecamatan Cigasong tetap memelihara ketertiban dan kehidupan bermasyarakat.

Selain kesadaran masyarakat, politisasi SARA juga dipengaruhi oleh sikap elit politik. Untuk hal ini, di kecamatan Cigasong Kabupaten Majalengka tidak ditemukan elit politik yang melakukan hal-hal yang bertolak belakang dengan nilainilai demokrasi. Semua pihak menjungjung tinggi nilai-nilai kebersamaan dan persatuan sehingga isu SARA di kecamatan ini dapat terbantahkan.

\section{d. Partisipasi Masyarakat untuk Mengikuti Pilpes 2019}

Partisipasi politik adalah kegiatan seseorang atau sekelompok orang untuk ikut secara aktif dalam kehidupan politik, antara lain dengan memilih pimpinan Negara dan secara langsung atau tidak langsung mempengaruhi kebijakan pemerintah (Public Policy). Kegiatan itu mencakup tindakan seperti memberikan suara dalam pemilihan umum, menghadiri rapat umum, mengadakan hubungan atau lobbying dengan pejabat pemerintah atau anggota parlemen, menjadi anggota partai atau salah satu gerakan sosial, dan sebagainya (Budiardjo, 2003).

Keterlibatan atau partisipasi rakyat sangat mendasar dalam demokrasi karena demokrasi tidak hanya berkaitan dengan tujuan sebuah ketetapan yang dihasilkan oleh suatu pemerintahan, tetapi juga berkaitan dengan seluruh proses dalam membuat ketetapan itu sendiri. Demokrasi memberikan peluang yang luas kepada rakyat untuk berpartisipasi secara efektif dalam proses pengambilan keputusan yang menyangkut kebijakan publik serta persamaan bagi seluruh warga negara dewasa untuk ikut menentukan agenda dan melakukan kontrol terhadap pelaksanaan agenda yang telah diputuskan secara bersama.

Berdasarkan data yang peneliti peroleh, didapatkan hasil bahwa partisipasi masyarakat pada Pemilihan Presiden 2019 di Kecamatan Cigasong Kabupaten Majalengka cukup tinggi, yakni sebesar $85,58 \%$. Selain berdasarkan data tertulis, peneliti juga memperoleh data berdasarkan hasil wawancara dengan warga, tokoh masyarakat, Panwascam maupun aparatur pemerintahan Kecamatan Cigasong terkait tingginya partisipasi masyarakat untuk mengikuti Pilpres 2019.

Tingginya partisipasi politik Kecamatan Cigasong Kabupaten Majalengka menunjukkan baiknya sikap masyarakat dalam menentukan pilihan dan arah menuju perubahan yang lebih baik kedepannya. Hal itu juga menjadi salah satu indikator keberhasilan dan kualitas pelakasanaan penyelenggaraan pemilu yang demokratis di Kecamatan Cigasong Kabupaten Majalengka melalui partisipasi masyarakat dalam mengikuti tahapan-tahapan pemilu.

\section{Kesimpulan}

Kesimpulan yang diperoleh dari penelitian ini menunjukan bahwa tidak ditemukan politisasi SARA di Kecamatan Cigasong Kabupaten Majalengka. Isu SARA yang sampai ke tengah masyarakat Cigasong hanya sebatas informasi dari media massa dan internet (media social), isu SARA tidak masuk secara langsung kepada masyarakat melalui provokasi seseorang atau kelompok. Kalaupun ada pelanggaran hanya sebatas 
pelanggaran biasa, tidak ditemukan politisasi SARA untuk memenangkan salah satu Paslon. Sedangkan partisipasi masyarakat untuk mengikuti Pilpres 2019 berdasarkan hasil wawancara dan observasi, partisipasi masyarakat untuk menyampaikan suaranya cukup tinggi yakni sebesar $85,58 \%$. Tidak adanya keluhan yang diterima peneliti terkait berkurangnya partisipasi masyarakat menunjukkan bahwa politisasi SARA hanya berkembang di media sosial semata dan tidak memberikan pengaruh negative terhadap partisipasi masyarakat Kecamatan Cigasong Kabupaten Majalengka untuk mengikuti Pilpres 2019. 
Ujang Permana dan Idris Handriana

\section{BIBLIOGRAFI}

Anggito, A., \& Setiawan, J. (2018). Metodologi penelitian kualitatif. CV Jejak (Jejak Publisher).

Budiardjo, M. (2003). Dasar-dasar ilmu politik. Gramedia pustaka utama.

Harnawansyah, M. F. (2019). Dinamika Politik Daerah Dalam Pelaksanaan Sistem Pemilu Umum Legislatif Daerah. Syntax Literate; Jurnal Ilmiah Indonesia, 4(9), $50-64$.

Kharisma, T. (2017). Konflik SARA pada pilkada DKI Jakarta di Grup Whatsapp dengan Anggota Multikultural. Penelitian Komunikasi, 20, 107-120.

Nawawi, H. (1993). Metode penelitian bidang sosial. Gadjah Mada University Press.

Sumardiana, B. (2016). Formulasi Kebijakan Penanganan Tindak Pidana Berbasis Isu Sara dalam Pemilihan Umum. Pandecta: Research Law Journal, 11(1), 80-95. 